\title{
DO JORNALISMO LITERÁRIO À OBJETIVIDADE JORNALÍSTICA: AS NARRATIVAS JORNALÍSTICAS E A TRADIÇÃO DAS NARRATIVAS REALISTAS/NATURALISTAS BRASILEIRAS
}

\author{
Nicoli Glória De Tassis Guedes é doutoranda em Comunicação Social na UFMG e integrante do Núcleo de Estudos em Narrativa e \\ Experiência "Tramas Comunicacionais". \\ E-mail: nicolitassis@gmail.com
}

Resumo

Este artigo investiga as principais conexões entre o fazer jornalístico e a tradição das narrativas realistas /naturalistas brasileiras. A partir de um breve resgate dos fundamentos da reportagem no país, buscaremos problematizar diversos traços estéticos, narrativos $\mathrm{e}$ ideológicos que marcam o diálogo entre o jornalismo e a literatura no Brasil.

\begin{abstract}
This article investigates the main connections between journalism and Brazilian realistic/naturalistic narratives' tradition. From a brief revision of news foundations in the country, we intend to debate various aesthetic, narrative and ideological peculiarities that mark the dialog between journalism and literature in Brazil.
\end{abstract}

\section{Apresentação}

A partir do século XIX, é possível se observar a acentuação do exercício de compreensão da realidade brasileira nas artes em geral. No campo literário, por exemplo, narrar a sociedade passa a ser um dos principais alvos dos escritores. A visão romântica ${ }^{i}$, que até então dominava a poesia e a prosa nacionais, cede espaço para as propostas do Realismo ${ }^{\mathrm{ii}}$ e do Naturalismo ${ }^{\mathrm{iii}}$ - movimentos literários herdados da Europa, especialmente da influência de França e Portugal. Com isso, Süssekind (1982) aponta para o início de uma tradição de narrativas realistas/naturalistas no Brasil, que se estenderia durante todo o século XX, perdurando até os dias de hoje. Dentre tais narrativas literárias, o presente trabalho busca investigar a inserção das jornalísticas.

Entendemos que entre os escritores jornalistas e as opções temáticas e estéticas das suas produções existe um complexo de tramas do contexto social que define as características das suas obras para além do estilo pessoal. Assim, tais escolhas não se conformariam por mera imposição de modelos externos, como por exemplo, o Realismo Social Europeu (final do século XIX) e suas variações ao longo do século XX (como será apresentado a seguir) ou ainda o novo jornalismo norte americano ${ }^{\text {iv }}$ (segunda metade do século $\mathrm{XX}$ ); nem pela genialidade isolada dos principais autores de cada período. Temos aqui um duplo movimento em que as opções temáticas e estéticas das narrativas são geradas nas tensões de cada sociedade em um dado momento histórico, nelas se integrando. Daí o esforço em compreender o diálogo entre os campos jornalístico e literário numa perspectiva historicamente situada.

Ao resgatar parte da trajetória do jornalismo e da literatura brasileiros a partir de 1870, com suas influências externas e transformações sofridas em solo nacional, 
buscaremos, assim, compreender o lugar da narrativa jornalística entre as realistas/naturalistas. Tal discussão, no entanto, afasta-se de qualquer caráter evolucionista ou escala valorativa, pois, levamos em consideração que o desenvolvimento da reportagem no país se dá por vias lacunares, marcado ora por traços de continuidade (dos seus princípios técnicos, estéticos, discursivos, narrativos e do modo de produção), ora pelo lacunar, sem se constituir, portanto, num movimento linear. Reconhecemos, assim, que apesar do gênero passar por modificações ao longo do tempo, a relação das formas dos textos jornalístico e literário com as formas da história não se dá de maneira diretamente correspondente, se constituindo num percurso sinuoso, marcado, em grande medida e em diversas nuances, pela descontinuidade.

\section{1) O Desenvolvimento da Reportagem: Entre o Literário e o Jornalístico.}

De acordo com Sodré (1999), a história da imprensa no Brasil começa no século XVI com os relatos oficiais e artigos de opinião. Décadas antes de assumir as peculiaridades que o tornam hoje um discurso, muitas vezes, apresentado como distinto e independente da literatura, o fazer jornalístico desenvolveu-se intimamente ligado com o literário. Os jornais impressos na cultura ocidental no século XIX, por exemplo, que em seus primórdios atuaram como uma importante arena de lutas políticas e divulgação de ideais partidários - traziam textos cuja estética se aproximava muito da literatura da época, sendo até então uma das únicas práticas que se dedicava à prosa. Dessa forma, o fazer literário se constituía em um alicerce em que o jornalismo, como prática emergente, poderia buscar seus contornos em um primeiro momento.

Se ainda não estava conformado um estilo jornalístico próprio de se escrever, também não havia a figura do jornalista como se conhece atualmente: um profissional tecnicamente preparado para exercer um papel central na narrativa cotidiana dos acontecimentos e fatos sociais. Assim, os primeiros profissionais a escreverem para os jornais eram especialmente os literatos da época, homens afeitos às letras preocupados especialmente com questões de ordem política, que contribuíram ainda mais para a conformação de uma estética literária nas páginas dos periódicos.

Segundo Costa (2005), antes da sua profissionalização integral, que só ocorreu efetivamente no Brasil a partir da regulamentação, em 1969, com a exigência do diploma, a atividade jornalística foi exercida por diversas camadas sociais, indistintamente, sob a única exigência de que o "jornalista" em questão tivesse uma história, pressuposta real, para contar aos outros. Nesse período, os fazeres jornalístico e literário contavam basicamente com os mesmos escritores jornalistas; tinham recorrentemente os mesmos objetivos de busca de uma identidade para o Brasil e mobilização política; sofriam juntamente o controle da metrópole sob o seu conteúdo; e se constituíam em instrumentos de denúncia social e ideais políticos.

Os livros e jornais brasileiros nasceram praticamente juntos e foram publicados pela mesma editora. O primeiro livro, Observações sobre o comércio franco do Brasil, é filho da mesma tipografia que a Gazeta do Rio de Janeiro. Nesse ponto, o jornalismo 
parece despontar mais aos olhos do público, conferindo status à figura do jornalista. "O processo de Independência acentuou esse caráter missionário: o intelectual considerado como mentor da sociedade, voltado para a aplicação prática das idéias. A imprensa foi o meio privilegiado de sua ação" (Lustosa, 2000, p. 33).

Nos 13 anos compreendidos entre a chegada da corte (1808) e a independência do Brasil (1822), o país vivenciou um período pouco produtivo para a literatura, ao passo que o jornalismo ampliava o seu campo de ação. Mesmo assim, o mercado de leitores ainda se mostrava bastante tímido e a maioria dos periódicos criados no período não conseguiu sobreviver por muito tempo:

\begin{abstract}
Especialmente com o fim do Conselho de Censura Prévia, multiplicaram-se os jornais, embora o mesmo não se possa dizer dos livros. Os dois únicos jornais com licença de impressão entre 1808 e 1829 - a Gazeta do Rio de Janeiro (1808-1820) e Idade d'Ouro do Brasil (1814-1820) - foram obrigados a disputar leitores com folhas, gazetas, pasquins, periódicos de todos os tipos, que nasciam e morriam em poucos meses, com raras exceções, como A Aurora Fluminense (1827-1839) e o próprio Correio Braziliense (1808-1821). (...) Em 1822, o diário A Malagueta, criado um ano antes, era o jornal de maior repercussão nacional e com o maior número de assinantes no Rio de Janeiro, quinhentas pessoas. O mercado para a literatura era ainda menor (Costa, 2005, p. 224).
\end{abstract}

Essa geração de escritores jornalistas é testemunha de um momento crucial na história da literatura e da imprensa brasileiras, que começa em 1840, quando o golpe da maioridade de D. Pedro II inaugura um novo tempo no jornalismo do Brasil. Os jornais panfletários e os pasquins políticos, que tiveram o seu momento de maior projeção a partir da volta de D. João VI a Portugal, cedem lugar para uma imprensa menos militante. Assim, os homens das letras encontram maior espaço nos jornais. A inserção do folhetim nos periódicos começa a formar um público para a ficção nacional e também para os jornais. A imprensa demonstrava um incrível potencial de alcance em um país de poucos leitores e livrarias. Às portas do século XX, praticamente todos os principais escritores do período publicariam seus romances primeiro nos jornais para depois lançar seus livros.

A partir do início do século XIX, as transformações sociais experimentadas pela sociedade ocidental, especialmente pelos países europeus e os Estados Unidos, já haviam começado a modificar o fazer jornalístico. O jornalismo brasileiro, claro, seria também confrontado posteriormente por tais modificações. Segundo Genro Filho (1987, p. 167), nesse período "ocorreram grandes transformações na imprensa, coincidindo com a expansão mundial do capitalismo e o aparecimento de inovações tecnológicas ligadas diretamente à reprodução e circulação das informações", tais como a invenção do telégrafo, da rotativa e da máquina de linotipo, estabelecendo-se, assim, "as bases materiais e sociais para um novo tipo de jornalismo".

Em 1880, a tipografia, acompanhando as transformações advindas da industrialização, deixa o seu caráter artesanal e assume ares de indústria. A sociedade capitalista brasileira demanda um novo tipo de prática jornalística, menos idealista e 
mais empresarial. No lugar dos longos textos de caráter explicitamente ideológico e declaratório, surgem narrativas curtas baseadas na lógica informativa. "O século XX se abre para o jornalismo brasileiro com a consciência de que a notícia é a sua prioridade". (Bahia, 1990, p. 131). Aos poucos, os jornais-tribuna do período anterior abandonam a opinião e cedem lugar para a informação.

Já nas primeiras décadas do século XX, a necessidade de abordar as questões mundiais que passaram a afetar toda a sociedade impunha ao jornalismo um ritmo frenético de trabalho e o alcance de um público muito mais abrangente e heterogêneo. É o início de uma era de racionalidade capitalista que transformaria a prática jornalística em uma verdadeira indústria da informação. Surge, então, nos Estados Unidos e posteriormente também no Brasil, o modelo de jornalismo objetivo, como uma espécie de "grito de independência" dos pressupostos centrais do fazer literário, pautado pelo ideal de uma escrita imparcial, simples e concisa, que rejeitava a carga subjetiva e as alegorias literárias.

Nesse contexto, a literatura e o jornalismo do período anterior - marcados pelo gosto ornamental e o beletrismo - estavam com os dias contados. Com o crescimento da industrialização, a partir da década de 1920, os escritores que atuavam nos jornais já não eram considerados estrelas, como na época em que Olavo Bilac e Coelho Neto, entre tantos outros, marcavam as páginas com seus longos exercícios literários. A esse novo jornalista não caberia produzir contos ou poemas; deveria agora se dedicar a reportagens, entrevistar, corrigir textos, editar o conteúdo e a forma do jornal, além de chefiar as redações.

Não foi na condição de criadores de narrativas admiráveis que Graciliano Ramos, Carlos Drummond de Andrade, Oswald de Andrade e toda essa geração de escritores inicialmente atuaram na imprensa e sim como "jornalistas braçais" ou "operários da informação". Curiosamente, Costa (2005) evidencia que foram eles mesmos - os literatos - que trouxeram para o fazer jornalístico a estética e os preceitos de uma literatura moderna, que economizava palavras e primava pela informação, muito antes que os lides ${ }^{\mathrm{v}}$, sublides ${ }^{\mathrm{vi}}$ e pirâmides invertidas ${ }^{\mathrm{vii}}$ fossem copiados do modelo norte americano.

Costa (2005) apresenta fortes evidências da proximidade entre os projetos literários e jornalísticos produzidos por autores realistas e modernistas brasileiros, na primeira metade do século XX. Ambos buscavam expulsar os mesmos intrusos: o uso exacerbado de adjetivos, a literatice e o beletrismo. Movidos por esse projeto modernista, os escritores implantaram diversas modificações na imprensa, ao assumir cargos importantes nas empresas jornalísticas. Os preceitos de cortar ao máximo as "gorduras" do texto e registrar as informações mais importantes com a maior precisão e economia possíveis são propostas estéticas que perduram, em grande medida, até os dias de hoje e podem ser observadas em qualquer manual de redação contemporâneo.

Se a literatura parnasiana foi separada da moderna na polêmica Semana da Arte

Moderna, em 1922, a imprensa experimentaria tal impacto na década de 1950, com a introdução do lide. O terreno já vinha sendo preparado pelos próprios escritores 
jornalistas brasileiros há três décadas. Contudo, a importação do modelo norte americano de objetividade consolidaria a expulsão do nariz-de-cera, ou seja, das divagações que antecediam o núcleo da informação nas matérias jornalísticas. Jornalistas como Samuel Wainer, Danton Jobim e Alberto Dines foram essenciais nesse processo. Depois de passarem uma temporada nos Estados Unidos, ajudaram a construir uma nova base para o jornalismo brasileiro, com a adoção da pirâmide invertida, a desvinculação dos cargos de repórter e redator, além da separação entre notícia e opinião. A profissionalização gradativamente daria vida própria à carreira jornalística, que deixa de ser apenas um meio viável para o aspirante a escritor conquistar o seu espaço. "Com isso, a imprensa ganhava valores estéticos particulares e seus próprios mecanismos de consagração" (Costa, 2005, p. 100).

Além da chegada dos tempos modernos, a imprensa absorve também os efeitos da $1^{\text {a }}$ Guerra Mundial, ou seja, passa a ficar ainda mais a mercê da "ditadura" dos acontecimentos. O que interessa é divulgar o que está acontecendo no país e no mundo, o mais rápido possível, com maior alcance e precisão do que os jornais concorrentes. A influência da imprensa francesa, mais prolixa e opinativa, dá lugar à norte-americana, movida pelos ideais de uma narrativa concisa e direta. Daí por diante, uma das tarefas da "ditadura da objetividade" seria firmar as fronteiras entre o jornalismo e a literatura.

Em meio à proliferação dessa ditadura da objetividade nas redações brasileiras, a reportagem parece ser o espaço consolidado para que o jornalista tenha livre trânsito às contribuições dos elementos estéticos e textuais literários. Lima (1995, p. 135) afirma que "de todas as formas de comunicação jornalística, a reportagem, especialmente em livro, é a que mais se apropria do fazer literário". O autor defende ainda que "à medida que o texto jornalístico evolui da notícia para a reportagem, surge a necessidade de aperfeiçoamento das técnicas de tratamento da mensagem (...) e os jornalistas sentiamse então inclinados a se inspirar na arte literária”.

Curiosamente, o conceito de objetividade dos fatos tal como conhecemos hoje já era trabalhado, ainda que não tivesse essa nomenclatura, pelos jornalistas brasileiros como uma herança da ideologia divulgada pela Escola Literária do Realismo Social. Santaella (1996) aponta que o fazer literário, em diversos períodos, especialmente antes da consolidação da imprensa tal como conhecemos hoje, chamou para si o lugar de reprodutor do real. Contudo, apesar de suas ferramentas que pressupunham a possibilidade de uma observação crua do presente em estado bruto, a literatura teve o seu anseio de transparência realista denunciado como ilusão de ótica nos falseamentos em que caiu o naturalismo.

Ao se ver obrigada a ceder espaço para os periódicos numa tarefa que estes, pelos seus próprios mecanismos de produção e distribuição, poderiam realizar de forma mais eficaz, a literatura descobriu a consciência do seu ser-linguagem: o realismo do discurso. O jornal por seu lado, após um primeiro momento (suas faces ainda artesanais) de importação de beletrismo literário, foi gradativamente desenvolvendo seu próprio know-how (pós-industrialismo) buscando para si uma imagem de objetividade, economia e imparcialidade que o mosaico jornalístico parecia realizar, satisfazendo a 
necessidade de condensação informativa e fornecendo ao leitor doses cotidianas para sua reserva de acontecimento (Santaella, 1996, p. 52).

\section{2) Realismo Social: o Embrião da Reportagem Brasileira.}

O realismo social surgiu no século XIX, na Europa, quando o romance se consolidou como um gênero literário de prestígio. Os romancistas desta corrente, representados, entre outros, por Balzac, Dickens, Dostoievski e Tolstoi, atuavam, de certa forma, como "repórteres" do seu tempo, ainda que seu trabalho se ofertasse assumidamente por vias ficcionais, ao contrário do fazer jornalístico que é regido por uma relação mais estreita com o real. O processo de construção de um romance demandava esforços, em alguma medida, muito parecidos com a prática do jornalismo contemporâneo, tais como, a investigação e a pesquisa de campo, na tentativa de reproduzir situações e acontecimentos da forma mais verossimilhante e próxima do real possível. "Esses escritores haviam conseguido desenvolver uma receita onde os costumes, a linguagem, as personagens eram desenvolvidos apoiados por um realismo detalhado, extraído do cotidiano. Os críticos costumavam confrontar a fidelidade das obras para com o real" (Lima, 1995, p. 141).

$\mathrm{Na}$ Inglaterra, Charles Dickens fazia levantamentos de ambientes sociais, costumes regionais, tipos humanos e usos de linguagem. Sua matéria-prima principal era as classes socialmente marginalizadas, ponto de partida para a maioria das suas construções literárias. Na França, Balzac primou pela precisão na observação da realidade, sendo considerado pela crítica um escritor exato na reprodução de ambientes. Fiódor Dostoievski descrevia detalhadamente a realidade urbana russa, com as suas agremiações de proletários, pequenos comerciantes, prostitutas, mujiques e estudantes, entre outros. Essas figuras, consideradas de menor importância no contexto social russo, ganhavam destaque de protagonistas nas obras.

Em Crime e Castigo, por exemplo, a cidade de São Petersburgo é o espaço sombrio onde se passa a narrativa, com ênfase para suas tavernas sujas e decadentes. Já em Os irmãos Karamazov, Dostoievski tece uma profunda análise das mazelas da sociedade russa, a partir de uma trama que envolve três irmãos e um parricídio. Nesse romance, as personagens são compostos por perfis humanos vis, como a prostituta Grúchenka, que debocha friamente de pai e filho que disputam, quase que de forma irracional, o seu amor. A narrativa é marcada por personagens de lugar social insignificante, como os mujiques que vagam pelas ruas da cidade, quase sempre bêbados; monges que desprezam os seus companheiros numa relação complexa de conflitos silenciosos; comerciantes corruptos; e outros tipos marginais que caracterizam esse ambiente urbano.

Ainda que essas narrativas retratem as impressões de escritores que, no geral, pertenciam ou queriam pertencer à classe burguesa, trazendo, consequentemente, o seu ponto de vista, o exercício empreendido aproxima-se do ideal de objetividade jornalística à medida que propõe um método de apuração in loco e prima pela descrição 
minuciosa do ambiente social, político, econômico e cultural para construir os seus relatos e personagens, princípios igualmente caros ao modelo de jornalismo objetivo.

Nota-se em tais autores do realismo social, a primazia por diversas características que dialogam com a prática jornalística contemporânea. Entre elas: a circunscrição exata de certo espaço e tempo; a proximidade dos temas tratados com a realidade compartilhada num dado período e sociedade; a ambientação social, política, econômica, cultural e histórica precisa de seus relatos; entre outras. Segundo Kovach e Rosenstiel (2003), esses preceitos foram sistematizados mais tarde pelo modelo de jornalismo norte americano, sob a chancela da objetividade, que durante o século XX se consolidou como uma importante fonte para a construção dos manuais de redação que balizam, de uma forma geral, a prática jornalística brasileira até os dias atuais.

$\mathrm{Na}$ última parte do século XIX, os jornalistas falavam sobre alguma coisa que chamavam de realismo, não objetividade. Essa idéia era a de que se os repórteres cavassem os fatos e os ordenasse direito, a verdade apareceria naturalmente. $\mathrm{O}$ realismo emergiu numa época em que o jornalismo se separava dos partidos políticos e se tornava mais preciso. Coincidia isso também com a invenção do que os jornalistas chamam de pirâmide invertida, na qual o profissional coloca os fatos partindo do mais importante até o menos importante, achando que com isso ajuda os leitores a entender as coisas de uma forma mais natural (Kovach e Rosenstiel, 2003, p. 114).

Nesse ponto, podemos suspeitar que o embrião da reportagem brasileira se constituiu na Escola Realista/Naturalista. Süssekind (1982) aponta para a tradição de uma estética realista/naturalista brasileira, consolidada ao longo do século XX, que teria como principal objetivo a construção ideológica, narrativa e discursiva de um determinado retrato de Brasil. De acordo com a autora, desde a consolidação da Escola Realista/Naturalista Brasileira, no final do século XIX, uma aliança estético-ideológica de construção da identidade nacional tem se repetido nas narrativas produzidas no país.

Nesse ponto, a autora chama a atenção para o fato de que, em geral, a historiografia literária brasileira tendeu a buscar, num primeiro momento, basicamente, influências e autenticidades. Assim, por não se poder negar que o realismo/naturalismo teve origem em outro lugar, quase sempre os textos brasileiros estiveram fadados a ser avaliados em comparação com os portugueses ou franceses. Dessa forma, apesar das contribuições reconhecidas da ideologia estética naturalista em sua adaptação brasileira, as duas únicas possibilidades de valorização da produção literária nacional pareciam ser: "uma extrema semelhança com o texto primeiro estrangeiro, ou uma extrema diferença, uma notável 'originalidade'. Ou fica valorizada uma repetição fiel do modelo estrangeiro, ou uma repetição fiel da própria identidade nacional” (Süssekind, 1982, p. 54).

Nas discussões do final do século XIX, por exemplo, a crítica dos intelectuais se focava nesse caráter de ideia importada da nova moda literária europeia. José Veríssimo na obra História da Literatura Brasileira (1954) é um dos que define a escola naturalista no Brasil apenas como uma "moda entre outras", que não teria fôlego para perdurar por muito tempo. 
Mais estreitamente ainda do que o nosso romantismo seguira o francês, arremedou o naturalismo indígena o naturalismo da mesma procedência, modelando-se quase exclusivamente por Emílio Zola e o seu discípulo Eça de Queiroz. De novelas, contos, curtas e ligeiras ficções e ainda romances, segundo a fórmula pessoal destes dois escritores, houve aqui fartura desde 1883 até o rápido esgotamento dessa fórmula pelos anos de 90, quando ela senão procrastinou em exemplares inferiores que importunamente ainda a empregavam (Veríssimo, 1954, p. 294).

Mas, se a crítica do autor se mostra negativa no que diz respeito à obediência aos moldes dessa escola, o mesmo não acontece com algumas contribuições da ideologia estética que atravessa o Naturalismo, tais como o sentimento de realidade e a busca pela representação da identidade e do cotidiano brasileiros.

Não seria, porém, justo contestar-lhe o bom serviço prestado, tanto aqui como lá, às letras. Ele trouxe à nossa ficção mais justo sentimento de realidade, arte mais perfeita da sua figuração, maior interesse humano, inteligência mais clara dos fenômenos sociais e da alma individual, expressão mais apurada, em suma, uma representação menos defeituosa da nossa vida, que pretendia definir (Veríssimo, 1954, p. 295-296).

Importação, tradução ou traição do modelo europeu, parece que as narrativas realistas/naturalistas brasileiras não teriam outro destino senão o legado da inferioridade, da eterna analogia e das comparações. Contudo, Sodré (1965) argumenta que o naturalismo não é incorporado à Literatura Brasileira por mero acidente. Para o autor, a adoção dos modelos francês (Zola) e português (Eça de Queiroz) é uma consequência das condições históricas do Brasil, naquele período. Mais do que fruto de uma influência externa, a adesão a essa proposta estética se constitui num movimento coerente com a realidade de um país que buscava se autoafirmar como nação e passava por profundas transformações econômicas, políticas e sociais.

Avançar pareceria sempre assumir as atitudes que assemelhassem o Brasil com a Europa que equiparassem às zonas mais desenvolvidas do mundo, que dissipassem a distância histórica. (...) Mas por outro lado, o naturalismo não havia ocorrido apenas por fôrça da influência externa, mas atendia também às condições internas, aquelas condições, peculiares à sociedade brasileira do tempo, em que suas manifestações situavam-se como protesto contra uma ordem de coisas, atendiam ao sentimento de inconformismo que se generalizava e encontrava na nova escola uma saída para expressar-se, em têrmos de literatura (Sodré, 1965, p. 160 e 174).

O autor destaca que a recepção favorável da escola realista/naturalista e do cientificismo, no final do século XIX, tem relação direta com o crescimento de uma pequena burguesia urbana, em contraste com o poder da "classe territorial", até então exclusivamente dominante. Assim, o naturalismo e o cientificismo eram os meios propícios para uma camada social, até então pouco expressiva, desenvolver uma linguagem própria para aumentar a sua influência política e cultural, acompanhando as transformações sociais do país. 
Não se trata aqui, no entanto, de abandonar a explicação simplista da importação de ideias estrangeiras para substituí-las pela relação não menos apressada da dependência das nossas ideias para com a nossa história econômica. $\mathrm{O}$ esforço do autor, do qual também compartilhamos, é tentar enxergar essa importação de dentro da realidade socioeconômica brasileira. Ou seja, avançar no entendimento das condições que levaram à adoção do modelo estético-ideológico provido pelo Realismo/Naturalismo e suas adaptações à sociedade de diferentes épocas. Daí deslocase a questão da influência externa (e o inevitável debate a respeito de subjugação e poder que esse caminho implica), para refletirmos sobre os fatores que levaram essas escolas tão bem se ambientarem no Brasil, trajetória que nos parece mais elucidativa.

A nova escola chega ao Brasil, assim, numa fase de mudança, quando velhas estruturas, profundamente ancoradas no passado colonial, sofriam forte abalo, quando a economia do país se modificava, inclusive passando o primado para o centro-sul, quando a sociedade denunciava as alterações pelo avultamento da pequena burguesia e pelo esforço da burguesia pela conquista de um lugar, e os acontecimentos políticos se sucediam acompanhados de fortes campanhas de opinião, e quando os contatos entre as diversas partes do país e deste com o mundo se arruinavam. O naturalismo não ocorre, pois, por simples acidente (Sodré, 1965, p. 168).

Assim como a entrada dessa escola literária no Brasil não ocorre por mera imposição ou acidente, a perpetuação da sua ideologia estética também é configurada pela conjuntura social, política, cultural e econômica em que o país se insere em diferentes momentos. De acordo com Senra (2006), entre 1912 e 1929 instaura-se um novo cenário, com um crescimento da produção industrial de cerca de 175\%. Apesar disso, a política econômica encontrava-se mais voltada para os lucros obtidos pelo cultivo e beneficiamento do café. Com a crise norte-americana de 1929, caem os índices de exportação do "ouro negro" brasileiro. Assim, após a Revolução de 1930, a saída é o estímulo ao desenvolvimento urbano e industrial. Em dez anos, esse setor cresceu aproximadamente $125 \%$, enquanto na agricultura os avanços não passaram de $20 \%$.

$\mathrm{O}$ autor afirma que esse quadro político-econômico teve fortes influências no panorama cultural brasileiro. O Modernismo - tão criticado durante a Semana de Arte Moderna - torna-se o principal movimento estético-literário pelo seu caráter antielitista e popular, influenciando também o jornalismo.

Esse novo quadro sócio-cultural enfraqueceu bastante a já abalada noção de identidade nacional baseada na raça e no meio, tão forte até o final do século XIX e tão defendida pelo Naturalismo. O elemento pobre sempre foi alvo da análise naturalista através do estudo do negro e do mestiço, sempre em detrimento destes em relação ao branco. Com esse novo panorama político-cultural, a elite intelectual branca vê-se cada vez mais acuada em sua visão de sociedade positivista e evolucionista. Uma nova forma de se ver a identidade nacional era necessária para atender a essa nova demanda social (Senra, 2006, p.38-39).

Esse período é reconhecido como um dos mais férteis do romance brasileiro, em que a herança do realismo/naturalismo se faz bastante presente, ainda que sem a carga 
ideológica cientificista do século XIX, conforme aponta Süssekind (1982). Os escritores do decênio de 1930 regatam a prosa realista/naturalista ao abordar temas que vão desde a miséria nordestina e a crise cafeeira, até o crescimento industrial e o fortalecimento de uma burguesia urbana cada vez mais afoita por um lugar na política nacional. Assim, é desenvolvida uma nova narrativa documental, que tem como proposta central a captação e transcrição do maior número de fatos sociais possíveis. "A proposta dessa safra de escritores é fazer com que o 'ler' equipare-se ao 'ver', ou seja, que uma leitura seja uma documentação fiel da realidade material sob um viés de crítica e denúncia” (Senra, 2006, p. 43).

Dessa forma, o autor destaca que a década de 1930 é marcada, por um lado, pela consciência do subdesenvolvimento brasileiro, e por outro, pela necessidade de resgatar a crença no progresso do país e num futuro revolucionariamente promissor. As diversas fraturas da nacionalidade, expostas pela produção artística do decênio de 1920, passam a ser vistas de forma unificada. Estava instaurado, assim, um terreno propício e fértil para que mais uma vez a construção de uma identidade nacional sem fraturas provesse um ideal de país compatível com a nação que se sonhava ter.

Os romances voltam a cumprir, na maioria das vezes, o reconfortante papel de construir um retrato de nação, em meio aos reflexos da crise cafeeira, a Revolução de Trinta, o tenentismo e os abalos nas estruturas locais do poder. Assim, a ideologia estética realista/naturalista se firma "como uma espécie de band-aid de uma sociedade cujas divisões estão patentes, mas encontram soluções nostálgicas, como a busca de um José Lins de seus 'verdes anos', ou teleológicas, como as utopias revolucionárias de um Jorge Amado" (Süssekind, 1982, p. 174).

A partir de 1970, a literatura assume uma postura parajornalística, com a edição de romances-reportagem que privilegiavam temáticas como a violência e a marginalização, com a finalidade de provocar o questionamento social de forma extremamente agressiva. Os famosos casos-verdade, como ficaram conhecidos, se baseiam na construção de personagens e histórias fictícias a partir de pessoas e fatos concretos. Nessa perspectiva, temos a construção do retrato de um Brasil amedrontado, que tinha como maiores inimigos justamente aqueles que deveriam defendê-lo: o Estado, a polícia e a justiça. É o momento de ficções marcadas por uma crítica social corrosiva, objetivando um realismo bruto e agressivo.

Também nos anos de 1970, diante do autoritarismo da Ditadura Militar, a crescente má distribuição de renda e o cerceamento cada vez maior da liberdade de expressão levaram à construção de um retrato de Brasil, agora através da denúncia dos problemas brasileiros, num misto de fatos jornalísticos e elementos literários. Hollanda e Gonçalves (1980, p. 58-59) classificam a produção literária desse período sob o seguinte prisma: "é a literatura de olho no jornalismo e a reportagem de olho na ficção", enquanto o romance-reportagem se firma como fruto de uma espécie de "neonaturalismo muito ligado às formas de representação do jornal". Esse novo naturalismo (assim nomeado por compartilhar diversas características já debatidas da escola introduzida no país no final do século XIX, mas, agora sob a chancela do 
noticiário) dá mais ênfase à informação do que à narração e o material dos romances é retirado, na maioria das vezes, das páginas dos jornais.

No contexto atual, defendemos que a prática da grande reportagem se aproxima da tradição das narrativas realistas/naturalistas por apresentar diversas estratégias e recursos semelhantes, tais como, a construção do efeito de real (a verossimilhança, o detalhamento dos fatos e a descrição minuciosa) e a proposta de desvendar os problemas nacionais (diálogo com questões sociais, a busca da verdade e construção identitária); e tende a se afastar à medida que abandona as explicações preconceituosas sobre a sociedade brasileira, presentes nas primeiras obras realistas/naturalistas, ao passo que também não pretende oferecer uma leitura reconfortante das problemáticas nacionais, diante de uma realidade social complexa e, por vezes, marcada por contradições, fragmentária demais para ser ordenada de forma una $^{\text {viii }}$.

Nesse sentido, percebemos que apesar de a escola realista/naturalista ter como proposta central atender a propósitos cientificistas, a sua experiência estética e literária foi muito além, especialmente se levarmos em conta que até o surgimento dessa escola as narrativas literárias e jornalísticas brasileiras pouco falavam da presença de negros ou mestiços como personagens centrais da nossa sociedade. Com as narrativas realistas/naturalistas, as classes de menor prestígio social ganham destaque dentro das obras. É também com a entrada do realismo/naturalismo no país que o Brasil aparece pela primeira vez como um espaço de miscigenação de três raças, com enfoque para a figura do mulato, ainda que sob uma ótica negativa.

Da mesma forma, foi através do retorno dessa ideologia estética que o mestiço reaparece como símbolo nacional; agora, sem caráter depreciativo. Nos anos de 1930, diversas obras se contrapõem à identidade brasileira construída com base na inferioridade do mulato diante da primazia branca, como por exemplo: Evolução Política do Brasil, de Caio Prado Jr. (1933), Casa Grande \& Senzala, de Gilberto Freire (1933) e Raízes do Brasil, de Sérgio Buarque de Hollanda (1936). Dentre estas três obras, destaca-se a de Gilberto Freyre pela reinterpretação da visão cientificista, substituindo a noção de "raça" pela de "cultura". Dessa forma, o autor distancia as noções biológicas e as sociais, ao trabalhar o elemento mestiço como um fator positivo. A partir de então, Senra (2002) apresenta que temos no Brasil a conformação de uma tradição de produções editoriais marcadas pela herança do caráter popular do período moderno que se presta, em grande medida, à defesa das classes menos privilegiadas e à composição de uma identidade nacional mais plural e multifacetada.

Revistas contemporâneas como Piauí (Editora Abril), Caros Amigos e Brasileiros são alguns exemplos de publicações que, em grande medida, seguem a tendência de abandonar as "macronarrativas da nação", para apostar em narrativas que não têm a pretensão de abarcar a totalidade, provendo um interessante mosaico lacunar e diverso - de sua sociedade e tempo. Tais publicações se debruçam sobre o universo dos homens e mulheres comuns e suas práticas cotidianas para contar histórias que vão além das categorizações rígidas e preconceituosas ("o meliante", "o favelado", 
"o trombadinha", "o analfabeto"...) que, paralelamente, ainda figuram diariamente nas páginas de diversos outros periódicos, especialmente no noticiário policial.

Nesse ponto, é preciso salientar que a periodização da literatura aqui apresentada em três momentos historicamente relevantes (final do século XIX, decênio de 1930 e a partir dos anos de 1970) não deve ser tomada de forma rígida, como um processo evolutivo ou valorativo que implicaria na crescente subjugação de uma fase sobre a outra; mas, em seu caráter heurístico que nos permite observar uma série de características temáticas e estéticas relevantes no conjunto das obras de cada período. Levamos em consideração que resquícios dessas três fases podem ser encontrados nas reportagens contemporâneas - objeto do presente trabalho - e, por isso, muitas vezes, se torna difícil apreendê-los de forma precisa, justamente por ser um exercício não categórico, marcado por porosidades, tensionamentos e lacunas.

\section{3) Jornalismo e Realismo: Modos de Narrar Análogos.}

Ao ser retomado em contextos culturais bastante diversos, o novo realismo/naturalismo assume as particularidades de cada período. Süssekind (1982) afirma que o ideário darwinista/determinista que marcou o final do século XIX cede lugar para uma visão mais econômica e materialista na década de 1930, para a partir de 1970 assumir um discurso mais ligado à credibilidade jornalística e à primazia da informação. Contudo, as técnicas narrativas, a construção de personagens e a predileção por temas sociais, muitas vezes, ligados à denúncia dos problemas brasileiros, são pontos comuns a todos esses períodos.

Nesse contexto, alinhamo-nos com a perspectiva elucidada de Coutinho (1980), que evidencia que essas características perpassam, em maior ou menor grau, todas as propostas de narrativas realistas presentes na produção brasileira (dentre as quais o presente trabalho parte do pressuposto que se pode incluir o exercício da grande reportagem impressa), constituindo-se numa forma de pensar e se expressar diante do mundo. O autor serve-se das oito qualidades dominantes apontadas por Hibard (1942), que serão apresentadas a seguir, para refletir sobre o lugar das narrativas realistas. Identificamos nessas oito características vários pontos de correspondência com os pressupostos do jornalismo, que parece eleger o comum, o ordinário como objeto.

No primeiro ponto, temos que o realismo busca a verdade, ou seja, um tratamento verdadeiro na composição da narrativa e a verossimilhança na construção dos fatos. Assim, o escritor realista procura fugir ao máximo dos artificialismos, tais como o uso exacerbado da emoção e uma visão demasiadamente ordenada da vida, uma vez que esta possui um ritmo extremamente irregular, como também pode se verificar no exercício da reportagem.

A forma mais comum usada pelo realismo de buscar a verdade é a construção de um retrato o mais próximo possível de seus personagens. Estes são, antes de tudo, seres concretos com características peculiares que lhes conferem o status de indivíduos. O enredo colabora para a interpretação de tais personagens, que se apresentam como seres 
humanos multifacetados, com razões, emoções, modos de agir, pensar e ser próprios. Na prática da reportagem a construção das personagens também assume lugar de destaque.

Desse modo, percebe-se que assim como o realismo, o jornalismo prima por encarar a vida objetivamente. O jornalista procura não se intrometer na narrativa, deixando que as personagens, os fatos e as circunstâncias atuem uns sobre os outros. Ao retratar algo, à semelhança das narrativas realistas, as reportagens tendem a dar-lhe sentido ou uma interpretação própria. A acumulação de fatos pelo método da documentação perde a sua neutralidade na seleção e síntese do enredo.

Assim como ocorre geralmente no jornalismo, o realismo dá primazia para a retratação da vida contemporânea. Sua preocupação central é com a discussão do momento presente. Qualquer motivo de conflito do homem com a sua época e/ou sociedade é fator desencadeador de uma obra realista. Grande parte da força da sua narrativa é tecida a partir de detalhes precisos. Os aspectos aparentemente insignificantes recebem lugar de destaque na composição de uma narrativa que assume "cores" de realidade. O trabalho minucioso de retratação de uma dada sociedade, época, ambiente ou tema acaba por definir o tom mais ou menos realista de uma obra.

A narrativa realista, geralmente, move-se lentamente, assim como ocorre com o exercício da grande reportagem, diferente da notícia, que é marcada pelo factual, pela síntese e a economia do relato. Pela própria característica da técnica de narração ser minuciosa, e pelo interesse predominante na caracterização, a narrativa dá a impressão de lentidão e de constantes vaivens. Isso porque a técnica realista apoia-se, principalmente, nas impressões sensíveis. Para tanto, a linguagem empregada é a mais próxima da realidade em questão, buscando simplicidade e naturalidade no fluxo narrativo.

Diante da correspondência de suas características estéticas e narrativas, suspeitamos não ser viável pensar o jornalismo como um campo distinto da literatura ou mesmo adotar o uso indiscriminado de expressões como "jornalismo literário" para qualificar produtos jornalísticos de maior fôlego (tamanho, profundidade da investigação, riqueza de detalhes e complexidade), tais como, reportagens especiais ou livros-reportagem, uma vez que, tal jargão pressupõe a existência de um fazer jornalístico que não seja literário.

Como vimos na contextualização histórica brevemente resgatada por este trabalho, o jornalismo no Brasil não apenas teve como fonte primeira o fazer literário, como também continua em constante interlocução com este até os dias de hoje. Apesar dos manuais de redação adotados pelos principais veículos de comunicação do país direcionarem uma maneira bastante rígida de perceber a prática jornalística, especialmente aquela presente nos periódicos e noticiários em geral marcada por textos informativos, precisos, claros e diretos -, várias dessas características são justamente frutos da interlocução com os pressupostos estéticos de movimentos literários como o Modernismo.

Mesmo na fase mais radical de busca de uma identidade eminentemente jornalística (percebida a partir da segunda metade do século XX, com a acentuação do 
processo de profissionalização) a proximidade dos textos jornalísticos com os literários não é de todo abandonada, ainda que passe a ocupar um espaço cuidadosamente delimitado e, por vezes, "vigiado", como é a separação dualística proposta pelo modelo norte americano, também adotada pelas redações brasileiras, entre as notícias chamadas de hard (factuais) e soft (comportamentais).

Nessa perspectiva de viés positivista, caberia ao jornalismo diário, pautado pelos ideais de isenção e imparcialidade, a cobertura dos fatos de "real interesse social", em um texto preciso e coeso, redigido sob a chancela da urgência da produção noticiosa factual. Já os demais acontecimentos, considerados "frios" ou de "interesse humano", poderiam incorporar elementos literários (compreendidos como "ficcionais" ou "subjetivos"), encontrando a sua melhor expressão no universo da reportagem, que se opõe à notícia pelo maior tempo de produção e pelo tratamento estilístico do texto mais cuidadoso.

Demarcar-se-iam, assim, dois espaços convencionais que, ainda que na prática não sejam tão rígidos como a dicotomia propõe, pautam, em maior ou menor grau, certo imaginário coletivo da prática da profissão: o jornalismo impresso tradicional, supostamente autônomo e singular, rígido com relação às inconvenientes "intromissões" do modo de narrar da literatura; e outro mais "maleável", que permite interlocuções mais explícitas com o fazer literário que lhe deu suporte nos primórdios. Contudo, em ambos os modelos as conexões com o universo da literatura estão inevitavelmente presentes, mais ou menos evidentes de acordo com as relações narrativas e discursivas que o texto em questão implica e imbrica.

Em outras palavras, podemos questionar a viabilidade da separação dualística entre jornalismo e literatura, uma vez que, mesmo as narrativas noticiosas que se pressupõem objetivas - numa perspectiva positivista norteada pela ilusória pretensão de expulsão absoluta da subjetividade (já amplamente questionada pela comunidade acadêmica) - são atravessadas por contribuições estéticas da prosa literária, construídas no contexto particular brasileiro. Com isso, observa-se que um dos principais pressupostos que parece hoje separar o "jornalístico" do "literário" na tentativa de instituir o jornalismo como um campo do conhecimento autônomo e distinto, advém, em parte, de uma herança da própria literatura.

Nesse ponto, uma indagação nos inquieta: que jornalismo não é literário? A resposta elucidada pela trajetória histórica da reportagem no país - todo fazer jornalístico, em alguma medida, é permeado por contribuições da literatura - nos leva a considerar o termo "jornalismo literário" redundante e pouco apropriado para descrever narrativas noticiosas que evidenciam de forma mais clara sua interlocução com a estética dos romances. Não se trata, no entanto, de uma relação de dependência, de influência (baseada na noção de poder e subjugação) ou de causa-efeito, mas de "contaminações" próprias do ofício de narrar de duas áreas de limites "porosos" e que têm compartilhado, em diversos momentos e instâncias, contextos, veículos, profissionais, fontes, recursos, métodos, temas e propostas estéticas, entre outros. 


\section{4) O Ideal de Objetividade, a Estética Realista e o Novo Jornalismo.}

Além dos fatores sociais, culturais, econômicos e políticos próprios da década de 1970 no Brasil brevemente resgatados neste trabalho, diversos pesquisadores apontam também a influência dos romances de não-ficção norte americanos, evidenciados pelo movimento que se convencionou chamar de novo jornalismo, para a adesão dos escritores jornalistas brasileiros a um estilo de reportagem afeito à estética dos romances realistas.

O novo jornalismo culminou nos Estados Unidos nos anos de 1960, por meio do trabalho de um grupo de repórteres dedicados às matérias especiais (soft ou frias), a maioria advinda da revista The New Yorker, sem que num primeiro momento estivessem organizados para lançar um novo movimento. A marca preponderante de tais trabalhos que, inclusive, lhes rendeu o título de novo jornalismo, é a experimentação de técnicas ficcionais para construir narrativas de não-ficção.

Nesse ponto, percebemos que as quatro características da proposta de narrativa jornalística norte americana apontadas por Wolfe (2005) - construção cena a cena, registro de diálogos completos, ponto de vista da terceira pessoa e registros de hábitos - são encontradas também nas reportagens de escritores jornalistas brasileiros publicadas muito antes da explosão do novo jornalismo e se aproximam das técnicas realistas advindas do fazer literário.

A construção cena a cena consiste em narrar a história como se os fatos estivessem acontecendo naquele mesmo momento, recorrendo-se minimamente à reconstituição histórica dos acontecimentos. Já o registro de diálogos completos é uma técnica bastante usada na literatura realista/naturalista, com a finalidade de prender a atenção do leitor e dar voz própria as personagens, humanizando-os. $\mathrm{O}$ autor chama a atenção para o fato de que escritores realistas como Dickens, por exemplo, constroem as personagens de forma tão singular através dos diálogos que concede aos leitores a sensação de que ele descreveu minuciosamente cada milímetro de sua aparência e personalidade.

O ponto de vista da terceira pessoa trata de apresentar cada cena por meio de um personagem em particular. Esse recurso confere a impressão ao leitor de estar dentro da obra, como se estivesse também vivendo ou testemunhando bem de perto o desenrolar dos acontecimentos. Um dos propulsores do novo jornalismo, Tom Wolfe, por exemplo, era conhecido pela crítica como "camaleão", por explicitar as marcas da mediação do texto (técnica de redação impensável no modelo norte americano da objetividade), inserindo em uma mesma passagem diversos pontos de vista: o seu próprio e o das personagens. Algumas vezes, a ousadia chegava à descrição detalhada de uma determinada cena ou contexto a partir do ponto de vista interior dos protagonistas do relato, como uma espécie de fluxo de consciência virtual. 
O registro de hábitos e costumes, por sua vez, refere-se à composição do enredo e das personagens ser impregnada pela sociedade e o tempo no qual estão inseridos. Gestos, maneiras, vestes, vocabulário, mobília, decoração, modos de viajar, manutenção da casa, relação familiar, trabalho... Enfim, quaisquer detalhes que possam simbolizar o status de vida da pessoa, usando essa expressão no sentido amplo de todo o padrão de comportamento e posses por meio do qual a pessoa expressa sua posição no mundo ou o que ela pensa que é seu padrão ou ainda o que gostaria que fosse. Estes detalhes não são apenas acessórios da reportagem, mas fundamentais para conferir realismo à narrativa, além de se constituírem num indicador do cuidado e profundidade na apuração dos fatos.

Aos poucos, os limites convencionais impostos pelo modelo tradicional de jornalismo foram transpostos, não só no que diz respeito à técnica de redação, quanto à própria ideia do que é um trabalho de reportagem. A apuração passou a ser muito mais intensa, além de exigir um tempo ainda maior. Essa geração de escritores jornalistas investia dias, semanas e, até mesmo, meses para pesquisar in loco tudo o que poderia contribuir para o enriquecimento de suas histórias. A construção das personagens passou a ocupar um espaço central nas narrativas jornalísticas. Os repórteres começaram a sair a campo para vivenciar de perto a realidade de seus personagens. Porque captar o real de maneira linear e lógica já não era mais suficiente. Era necessário somar a isso a experiência de vida, que não pode ser obtida na face objetiva das coisas.

O novo jornalismo, enfim, trouxe à luz o que era considerado imaterial, em um texto marcado por um fino tratamento da linguagem. Dessa forma, abriu caminho para trabalhar a narrativa jornalística - produzida no bojo da indústria da informação como uma forma de arte. Além disso, ajudou a tornar evidente a face que, ainda que seja negada diversas vezes pela perspectiva cartesiana assumida pelo ideal de objetividade, é inerente, indistintamente, a qualquer texto noticioso: sua condição de construção e não de espelho do real. Ao distanciar-se dos recursos de controle da subjetividade, os escritores jornalistas assumiram o seu fazer como um relato interpretativo, a partir de uma perspectiva possível. Ciente da impossibilidade de ofertar o real em sua forma "bruta", a legitimidade jornalística se aproxima dos critérios de verossimilhança, buscando produzir uma descrição mais credível da realidade, a qual, por ser assumidamente apreciativa, está sujeita ao encontro com os interlocutores.

Dessa forma, abandona-se a ideia de que o jornalismo tem a sua credibilidade enraizada na possibilidade de ser fiel na reprodução dos fatos, rumo a uma suposta narrativa "pura" sobre o real, diante da constatação de que, apesar de possuir raízes no real (numa dada sociedade e tempo), a narrativa jornalística e o ordenamento do mundo que promove não existem como objeto da mesma forma em outro lugar, a não ser nas páginas que a materializa.

Dessa forma, ainda que possa ser verídica e conter diversos elementos bastante verossímeis, a narrativa jornalística jamais será "a verdade" que tanto o ideal de objetividade apregoou, num viés positivista. Admite-se, assim, que o texto 
noticioso oferece uma organização mutável de dados provisórios do cotidiano, em busca de uma verdade que sempre recua, pois, de fato, o que está em questão não é o seu encontro, mas, a sua busca. Nessa perspectiva, os repórteres - impossibilitados de ofertar a verdade absoluta - servem-se dos pressupostos centrais da objetividade (isenção, imparcialidade, verificabilidade e idoneidade, entre outros) para produzir um relato verdadeiro, de acordo com os princípios éticos que regem a profissão (interesse público, busca da verdade, acionamento de fontes consideradas fidedignas, oportunidades iguais para todos os lados envolvidos, etc.).

Inúmeros trabalhos jornalísticos publicados em forma de livro se constituem em exemplos interessantes da interlocução do jornalismo brasileiro com a estética realista/naturalista, bem como com as características atribuídas ao novo jornalismo. Grandes reportagens que, à semelhança do intercâmbio entre as redações e editorias ocorrido durante todo o século $\mathrm{XX}$, demonstram que os jornalistas continuam a transitar para o campo dos homens das letras. Agora, oferecendo uma narrativa de denúncia social, numa relação que se propõe direta com a realidade do país.

Diversos autores e obras se destacam no contexto brasileiro, entre eles: Fernando Morais - Ilha (1976), Olga (1985), Chatô: O rei do Brasil (1994), Corações Sujos (2000); Zuenir Ventura - 1968: O ano que não terminou (1980), Cidade Partida (1994), Minhas histórias dos outros (1999), Chico Mendes: Crime e Castigo (2003); José Louzeiro - O estranho hábito de viver (1978), Infância dos mortos (1977); Caco Barcelos A revolução das crianças (1982), Rota 66: a história da polícia que mata (1992); Abusado: o dono do morro Dona Marta (2003), entre tantos outros.

\section{Considerações finais}

No decorrer deste trabalho reiteramos a noção já amplamente debatida de que a prática da reportagem e do próprio jornalismo não pode ser resumida à aplicação de fórmulas ou à mera reprodução do real. A correspondência com características próprias da literatura realista/naturalista percebida na trajetória de conformação do gênero reportagem no Brasil evidencia tantas tensões, vozes e práticas discursivas que reduzir o fazer jornalístico a uma simples técnica ou ao acionamento mecânico de regras seria perder a riqueza da sua dimensão, do seu próprio objeto.

Movidos pela percepção de que a prática jornalística extrapola o próprio campo do jornalismo, apontamos a reportagem brasileira como um produto intrinsecamente ligado aos meios literário e editorial. Com isso, pressupomos que a ideologia estética realista/naturalista se constitui no pano de fundo a partir do qual diversos escritores jornalistas têm assumido o papel de narrar a sociedade, apontar os problemas e promover a denúncia social.

Além disso, ainda que não possamos desconsiderar o diálogo entre o 
jornalismo brasileiro e o norte americano, é preciso ponderar que talvez tal modelo tenha sido tão bem aceito pelos nossos jornalistas e leitores justamente porque já existia uma tradição desse tipo de narrativa na conformação do nosso jornalismo impresso. Como vimos anteriormente, desde o final do século XIX, temos construído um terreno fértil para o desenvolvimento da reportagem como um gênero jornalístico, com indícios estéticos da narrativa literária realista/naturalista. Mesmo sem a assinatura ou o glamour do novo jornalismo, suspeitamos que este já não fosse tanta novidade assim quando cruzou o oceano em nossa direção.

Assim, não podemos reduzir a termos simples a relação de influência entre o romance de nãoficção norte americano e a grande reportagem brasileira. Num breve movimento de olhar para a produção do início do século $\mathrm{XX}$, percebemos um indício para a resposta a essa questão. Muito antes do nascimento do novo jornalismo, encontramos em meio à conformação da reportagem como um gênero jornalístico no Brasil, uma estreita relação entre literatura, registro histórico e jornalismo.

Delimitações e categorizações à parte, no exercício diário as regras e dicotomias que parecem instituir o jornalismo como um campo autônomo sempre serão marcadas por exceções. Além disso, tentar apagar inteiramente os traços de uma origem pode se constituir num perigoso exercício de apagamento de si mesmo. Um vestígio, por menor que se apresente, sempre se manifestará, ainda que sob a forma de resistência.

\footnotetext{
'Dentro de uma proposta tradicional de periodização da literatura brasileira, os conceitos norteadores da Escola Literária do Romantismo, de forma generalista, são considerados antagônicos aos ideais do Realismo e, consequentemente, ao Naturalismo. Inclusive, nessa linha de pensamento, a adoção da visão realista/naturalista é comumente associada à derrubada da visão romântica na prosa e na poesia nacionais. Contudo, essa postura tem sido amplamente discutida e questionada pelos estudos literários contemporâneos que, numa perspectiva pós-desconstrutivista, repudiam a adoção de conceitos rígidos e as demarcações opositivas/dualísticas das escolas literárias. Alinhamo-nos com essa segunda proposta por reconhecer, dentre outros fatores, que o Romantismo brasileiro já traz diversos traços realistas, como a preocupação com a retratação fiel da sociedade e a busca por uma identidade nacional sólida.

ii A palavra realista deriva de real, oriunda do adjetivo do baixo latim realis, reale, por sua vez, derivado de res, coisa ou fato. Real+ismo (sufixo denotativo de partido, seita, crença, gênero, escola, profissão, vício, estado, condição, moléstia, porção) é palavra que indica preferência pelos fatos e a tendência de encarar as coisas tais como seriam numa dada realidade. Em literatura, o Realismo opõe-se habitualmente a idealismo (e a Romantismo) em virtude da sua opção pela realidade tal qual e não como deve ser.Assim, em crítica literária, como refere M.C. Beardsley, no Dictionary World Literature, de J. T. Shipley, o termo designa as obras literárias modeladas em estreita imitação da vida real e que retiram seus assuntos do mundo real, encarado de maneira objetiva, fotográfica, documental" (Coutinho, 1980, p. 185).

iii "É o Realismo fortalecido por uma teoria peculiar, de cunho científico, uma visão materialista do homem da vida e da sociedade. A palavra Naturalismo é formada por natural+ismo, e significa, em filosofia, a doutrina para qual na realidade nada tem um significado supernatural e, portanto, as leis científicas, e não as concepções teológicas da natureza, é que possuem explicações válidas; em literatura, é a teoria de que a arte deve conformar-se com a natureza, utilizando-se dos métodos científicos de observação e experimentação no tratamento dos fatos e das personagens" (Coutinho, 1980, p. 188).

iv Gênero jornalístico originado na imprensa dos Estados Unidos, popularizado especialmente pela revista The New Yorker, na década de 1960, que tem como principais prepulsores os escritores jornalistas Tom Wolfe, Gay Talese, Norman Mailer e Truman Capote. Suas obras, muitas vezes lançadas em forma de livro e classificadas como romance de nãoficção, têm como principal característica o uso de técnicas ficcionais no exercício da reportagem, rompendo com o ideal de objetividade absoluta e assumindo abertamente a subjetividade como um dos componentes fundantes da narrativa.
} 


\footnotetext{
${ }^{\mathrm{v}}$ Primeiro parágrafo do texto jornalístico, publicado geralmente em jornais impressos diários, formulado a partir da resposta aos cinco pontos primordiais da notícia: quem, como, onde, quando e porquê.

${ }^{\text {vi }}$ Parágrafo subsequente ao lide, em que são desenvolvidos os principais pontos da notícia.

vii Estrutura narrativa que abandona a ordem cronológica comumente usada ao se narrar uma história (início, desenvolvimento, clímax e fim) e começa a narrativa pelos fatos mais importantes (clímax) seguindo para os detalhes que contextualizam o relato em questão.

viii $\mathrm{Na}$ pesquisa concluída em 2007, fizemos um levantamento de mais de 550 livros-reportagem publicados ou republicados no Brasil entre 1970 a 2007, pelas principais editoras e instituições de fomento à cultura do país. Os títulos mapeados têm em comum a temática sobre a realidade brasileira ou sobre a experiência de escritores jornalistas brasileiros em viagem ou cobertura internacional, e podem ser facilmente encontrados em livrarias, diretamente com as editoras ou nos principais sebos virtuais do país, atualmente. A partir da análise mais detalhada de dois destes - Rota 66: a história da polícia que mata e Abusado: o dono do morro Dona Marta, ambos de Caco Barcellos - demonstramos como na contemporaneidade a macronarrativa da nação tende a ceder o lugar a uma narrativa mais fragmentária, sem a pretensão de abarcar a totalidade, construindo perfis humanos e sociais que fogem da lógica do estereótipo, muitas vezes reiterada nos periódicos e noticiários em geral. Ver: Guedes, Nicoli Glória De. Nos rastros de Abusado e Rota 66: o livro-reportagem e a tradição das narrativas realistas/naturalistas brasileiras. Dissertação de Mestrado. Belo Horizonte: PPGCOM/UFMG, 2007.
}

\section{Referências Bibliográficas}

BAHIA, Juarez. Jornal, história e técnica 1 - história da imprensa brasileira. São Paulo: Ática, 1990.

COSTA, Cristiane. Pena de Aluguel: escritores jornalistas no Brasil - 1904 a 2004. São Paulo: Companhia das Letras, 2005.

COUTINHO, Afrânio. Introdução à literatura no Brasil. Rio de Janeiro: Civilização Brasileira, 1980.

GENRO FILHO, Adelmo. O segredo da pirâmide - para uma teoria marxista do jornalismo. Porto Alegre, Tchê, 1987.

HIBARD, A. Writers of the Western World. Boston: Houghton Mifflin, 1942.

HOLLANDA, Heloisa Buarque. GONÇALVES, Marcos Augusto. A ficção da realidade brasileira. In: NOVAES, Adalto (org). Anos 70: Ainda sob a tempestade. Rio de Janeiro: Aeroplano / Editora Senac Rio, 2005. (p. 97-159)

KOVACH, Bill; ROSENSTIEL, Tom. Os elementos do jornalismo. São Paulo: Geração Editorial, 2003.

LIMA, Edvaldo Pereira. Páginas ampliadas: O Livro-reportagem como extensão do jornalismo e da literatura. $2^{\text {a }}$ Ed. Campinas: UNICAMP, 1995.

LUSTOSA, Isabel. Insultos impressos. São Paulo: Companhia das Letras, 2000.

SANTAELLA, Lúcia. Cultura das Mídias. São Paulo: Experimento,1996. 
SENRA, Flávio Pereira. A herança do período naturalista nas letras do século XX. Dissertação de Mestrado em Literatura Comparada. Rio de Janeiro: Universidade Federal do Rio de Janeiro, 2006.

SODRÉ, Nelson Werneck. História da imprensa do Brasil. $4^{\text {a }}$ Edição (atualizada). Rio de Janeiro: Mauad, 1999.

O Naturalismo no Brasil. Rio de Janeiro: Civilização Brasileira, 1965.

SÜSSEKIND, Flora. Tal Brasil, qual romance? Rio de Janeiro: Achiamé, 1982.

VERÍSSIMO, José. História da Literatura Brasileira. Rio de Janeiro: José Olympio, 1954.

WOLFE, Tom. Radical Chique e o Novo Jornalismo. São Paulo: Companhia das Letras, 2005. 